\title{
A Questionnaire Study to Evaluate the Knowledge of Healthcare Providers in Differentiating Between Vertigo and Dizzy Patients, In KSA
}

\author{
Nada ${ }^{1 *}$, Abdulaziz D ${ }^{2}$, Abdulrahman B ${ }^{3}$, Meashal Z ${ }^{3}$, Ahmed AlHmadi ${ }^{4}$, and Mohammed Ayas ${ }^{5}$ \\ ${ }^{1}$ Department of Audiovestibular, Saudi Arabia \\ ${ }^{2}$ Department of Medical intern, Saudi Arabia \\ ${ }^{3}$ Department of Medical Student at King Suad Bin Abdulaziz Saudi Arabia \\ ${ }^{4}$ Department of Neuro-Otologist, Associate Professor, united arab emirates \\ ${ }^{5}$ Department of Audiovestibular, Associate Professor, united arab emirates \\ *Corresponding author: Nada J, Department of Audiovestibular, Sharjah University, Saudi Arabia \\ Submission: 㘹 December 19, 2018; Published: 海 February 08, 2019 \begin{abstract}
survey study will be conducted among different healthcare professionals in Saudi Arabia. However, the main focus specialties ER, family medicine, ENT, neurology, physical $\backslash$ occupational therapy and audiology department. The questionnaires will be given to the multi- center to study the rate of knowledge the difference between the vertigo and dizzy patients among healthcare providers. The questions were develop based on regular case history taken and a part of it based on earlier studies for assessing patient's knowledge among vertigo. The interpretation of each survey item was assessed by 10 nominees' therapists and physicians, reviewed the survey to evaluate, flow, clarity and validity.
\end{abstract} \\ Abstract
Objective: The primary objective of this study was to evaluate the knowledge among healthcare providers. Patients and Method: A cross sectional \\ Abstract
Objective: The primary objective of this study was to evaluate the knowledge among healthcare providers. Patients and Method: A cross sectional
}

Conclusion: There are a quiet several participants in the study that were found to be lacking the basic knowledge of dizziness and vertigo $64.1 \%$ Moreover, upon going deeper in the study by giving more thorough questions, a plurality of them were found to be challenged especially in the protocols of diagnosing.

Keywords: Knowledge; Vertigo; Dizziness

\section{Introduction}

The vertigo and dizziness consider the most common disorders seen in the Emergence Room ER. In U.S 1991 doctors reported $5,417,000$ of patients who have been admitted to the hospital due to dizziness or vertigo [1]. The physicians sometime find difficulties to quantify patients who are having vertigo or dizziness /imbalance which can vary depending on the underlying cause. As the patients cannot describe their symptoms clearly because the differences between the vertigo and dizziness is almost the same for them specially in Arab population where the both words hold the same meaning. They either feel it as sensation of lightheadedness (where by the individual describes it as weakness $\backslash$ pass out, or as vertigo the sensation of spinning). It is important that the health care providers understand the main complain of the patients, in order a proper diagnosis can be taken, and patient can begin the treatment.

A body system including motor, vision, and the balance organ in the inner ear must works normally in order to maintain body balance. Human body can maintain the balance by at least receiving signal from to systems. However, if a patient start experiencing balance problèmes than most properly two systems aren't functioning well. A vertigo well known as a sensation of rotation, or the world spinning even when the patient perfectly still. It can be caused by the inner ear disorders, head-neck injury, trauma, CNS Tumor, Cerebrovascular diseases of the cerebellum, vestibular nuclei or their connection to the brain stem (VBI), and MS (multiple sclerosis). Dizziness is one of the most common symptoms that will promote a person to seek medical care. It is a term used to describe a range of sensations, such as feeling faint, woozy, weak or unsteady. Dizziness that creates the false sense that you or your surroundings are spinning or moving is called vertigo.

In 1991-1993 the US Department of Health and Human Services study showed a general population of all ages about 347,000 hospitalier per year are incurred because of vertigineuse syndromes,' 202,000 because of 'labyrinthites' and 184,000 because of 'labyrinthitis unspecified,' with several thousands more accounted for by other balance disorders, e.g., Meniere's disease" [2]. Other studies showed " $35.4 \%$ of US adults aged 40 years and older (69 million Americans) had vestibular dysfunction from 2001 through 2004" [3]. However, another study showed approximately 
four percent (almost eight million) of American adults report a chronic problem (lasting three months or longer) with balance, while an additional 1.1

percent (2.4 million) of American adults report a chronic problem with dizziness alone" [4]. "Recent study showed the most common diagnosed disorder was benign and Benign paroxysmal positional vertigo $(20 \%)$. Potentially life-threatening cases diagnosed were cerebellar infarct and posterior fossa space occupying lesion (5.3\%)" [5]. The important for healthcare professionals to know how to take excellent case history. Therefore, the primary objective of this study was to evaluate the knowledge among healthcare providers. Whereas the second primary objective to assess the referring criteria among different specialty to differentiate between dizzy and vertigo patients with short pride of time.

\section{Materials and Methods}

A cross sectional survey study will be conducted among different healthcare professionals in Saudi Arabia. However, the main focus specialties ER, family medicine, ENT, neurology, physical \occupational therapy and audiology department. The questionnaires will be given to the multi- center to study the rate of knowledge the difference between the vertigo and dizzy patients among healthcare providers. Then the results will be discussed and the second part to compare a different referring criterion among Saudi Arabia hospital (still under processing). The Results will be represented in terms of content and percent.

The questions were develop based on regular case history taken and a part of it based on earlier studies for assessing patient's knowledge among vertigo [6,7]. The interpretation of each survey item was assessed by 10 nominees' therapists and physicians, reviewed the survey to evaluate, flow, clarity and validity.

\section{Primary outcome analysis}

The results will be reported in percent with corresponding 95\% confidence limits.

\section{Questionnaire}

\section{Demographic Data}
Age
1. $25-34$ years
2. $35-44$ years
3. 45 - 54 years
4. >50years

\section{Gender}

1. Male

2. Female

\section{Nationality}

1. Saudi
2. Non-Saudi

Specialty

1. ENT

2. ER

3. Family medicine

4. Neurology

5. Audiology

6. $\mathrm{PT}$

7. OT

8. Other...........

\section{Job position}

1. Consultant

2. Fellow

3. Specialist

4. Resident

5. Therapist

6. Intern

years of experiences?

1. 0-3 Years

2. 4-6Years

3. 7-10 Years

4. More than 10 years

Did you take any vestibular courses before?

1. No

2. Yes

\section{Part one}

Instructions: Please choose your suitable answers from the options * Q1-9 basic knowledge of vertigo [8]

\section{Vertigo is?}

1. Faint

2. Spinning /rotation

3. unsteady gait

4. I don't know

How do you define a patient with rotation or movement of one's self or of one's surroundings in any plane?

1. Lightheadedness

2. Imbalance 

3. Vertigo
4. I don't know

Vertigo can be associated with?

1. Nausea / vomiting

2. Tinnitus

3. Hearing loss

4. Aural fullness

5. Headache

6. All of the above

7. I don't know

What are the possible causes of having all these symptoms (dizziness, headache, unsteady gait and vomiting)? You can choose more than one

1. Hypoglycemic

2. Middle ear disease

3. Hypertension

4. head trauma (Concussion)

5. I don't know

Is nystagmus consider sign associated with of having vertigo?

1. Always

2. Usually

3. Never

4. I don't know

Can unsteady gait or sudden fall be associated with vertigo?

1. Always

2. Usually

3. Never

4. I don't know

Is vertigo considered to be a part of dizziness?

1. No

2. Yes

3. I don't know

Can vertigo be associated with migraine?
1. No
2. Yes
3. I don't know

A dizzy patient in the emergency room must be evaluated by?

1. ENT

2. Emergence physician

3. Neurology \neurosurgeon

4. Audiologist $\backslash$ vestibular therapist

5. Orthopedic

6. Internal medicine

Q10 - 20 knowledge of vestibular tests and disorders

Do you know any of these clinical tests? (please check all of the tests that you know)?

1. Rhomberg Test

2. Fukuda stepping test

3. Dix-Hallpike

4. Gait walking test

5. Ocoular motor vestibular test (saccade, tracking, optoknetic)

6. Neurological test (Skew Deviation, Head ImpulseNystagmus- Test of Skew, VAT)

7. Head shaking test

8. None

Have you done any of the previous tests before?

1. No

2. Yes

Does any of the clinical tests make it easier for you to diagnose patients?

1. No

2. Yes

Is vestibular neuritis more likely be to develop after Upper respiratory infection?
1. No
2. Yes
3. I don't know

Negative Dix-Hallpike manoeuvre will rule out vertigo and dizziness patients?

1. No

2. Yes

3. I don't know 
Can basilar artery dissection develop vestibular impairment?

1. No

2. Yes

3. I don't know

What is the most common vestibular disorder?

1. Benign paroxysmal positional

2. Meniere's disease

3. Ototoxicity

4. Perilymph fistula

5. I don't know

Which of the following tests can help you in diagnosing benign paroxysmal positional vertigo?

1. The Dix-Hallpike / supine roll test using VNG

2. Video Head Impulse/Thrust test

3. Vestibular evoked myogenic potentials

4. I don't know

How can you differentiate between central and peripheral causes of vertigo?

1. Direction of the nystagmus

2. Vestibular tests

3. Associated symptoms

4. Absence of CNS symptoms

5. I don't know

When do you refer patients with dizziness or vertigo to the neurology department?

1. persisted nystagmus more than 48 hours not positional

2. Acute vertigo

3. sever headache

4. Sudden Unilateral deafness

5. facial nerve palsy

6. I don't know

When do you refer patients with dizziness or vertigo to ENT?

1. Hearing loss

2. Aural fullness

3. Acute /chronic vertigo

4. Recent ear / neck surgeries
5. loss of conscious

6. chronic middle ear diseases

Result

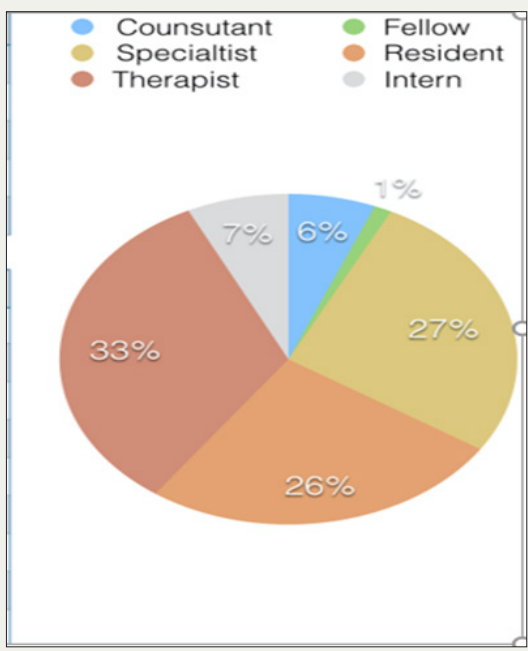

Figure 1: shows the job positions.

Table 1: summarizes the percentage of participated specialties.

\begin{tabular}{|c|cc|}
\hline Variables & N (\%) \\
\hline \multicolumn{2}{|c|}{ Gender } \\
\hline Male & & $65(40 \%)$ \\
\hline Female & & $96(60 \%)$ \\
\hline Saudi & Nationality & \\
\hline Expatriates & & $126(78.3 \%)$ \\
\hline
\end{tabular}

Table 2: shows the job positions.

\begin{tabular}{|c|c|}
\hline \multicolumn{2}{|c|}{ Age Group in Years } \\
\hline $25-34 \mathrm{Y}$ & $117(72.7 \%)$ \\
\hline $35-44 \mathrm{Y}$ & $31(19.3 \%)$ \\
\hline $45-50 \mathrm{Y}$ & $7(4.3 \%)$ \\
\hline$>50 \mathrm{Y}$ & $6(3.7 \%)$ \\
\hline
\end{tabular}

In our study the total number of 161 participant where female represent $(60 \%)$ male $(40 \%)$. which summarizes the age group, where about 117 participate represent (25-34Y, 72.7\%), 31 P (3544 Y, 19.3\%) and the about 7 P (45-50 Y, 4.3\%) / 6 P (>50 Y, 2.6\%) (Table 1-4); (Figure 1) 
Table 3: summarizes the answers in each question (percentage).

\begin{tabular}{|c|c|}
\hline Specialty & Total of 161 (\%) of Respondents \\
\hline PT & $43(27 \%)$ \\
\hline Audiology & $28(17 \% 0$ \\
\hline Family medicine & $20(13 \%)$ \\
\hline OT & $16(10 \%)$ \\
\hline ER & $15(9 \%)$ \\
\hline ENT & $12(7.5 \%)$ \\
\hline Neurology & $6(4 \%)$ \\
\hline Internal medicine & $3(2 \%)$ \\
\hline Paediatric & $2(1.3 \%)$ \\
\hline Orthopedic & $2(1.3 \%)$ \\
\hline ICU & $2(1.3 \%)$ \\
\hline Cardiology & $1(0.6 \%)$ \\
\hline Urology & $1(0.6 \%)$ \\
\hline Pulmonology & $1(0.6 \%)$ \\
\hline Optometrist & $1(0.6 \%)$ \\
\hline Neurosurgery & $1(0.6 \%)$ \\
\hline
\end{tabular}

Table 4:

\begin{tabular}{|c|c|c|c|c|c|c|c|}
\hline Questions & & & & & & & \\
\hline Vertigo & $\begin{array}{c}\text { unsteady gait } \\
2.5 \%\end{array}$ & faint $3.1 \%$ & $\begin{array}{l}\text { spinning/ } \\
\text { rotation } \\
93.8 \%\end{array}$ & $\begin{array}{c}\text { I don't know } \\
0.6 \%\end{array}$ & & & \\
\hline $\begin{array}{l}\text { How do you } \\
\text { define a } \\
\text { patient with } \\
\text { rotation or } \\
\text { movement } \\
\text { of one's self } \\
\text { or of one's } \\
\text { surroundings } \\
\text { in any plane? }\end{array}$ & $\begin{array}{c}\text { light-headedness } \\
4.3 \%\end{array}$ & $\begin{array}{c}\text { imbalance } \\
10.6 \%\end{array}$ & vertigo $82 \%$ & $\begin{array}{c}\text { I don't know } \\
3.1 \%\end{array}$ & & & \\
\hline $\begin{array}{l}\text { Vertigo can } \\
\text { be associated } \\
\text { with? }\end{array}$ & $\begin{array}{c}\text { Nausea/ vomiting } \\
6.8 \%\end{array}$ & Tinnitus $1.2 \%$ & $\begin{array}{c}\text { Hearing loss } \\
1.3 \%\end{array}$ & $\begin{array}{c}\text { Aural fullness } \\
0\end{array}$ & Headache 0 & $\begin{array}{c}\text { All of the } \\
\text { above } 87.7 \%\end{array}$ & $\begin{array}{c}\text { I don't know } \\
1.2 \%\end{array}$ \\
\hline $\begin{array}{l}\text { What are } \\
\text { the possible } \\
\text { causes of } \\
\text { having all } \\
\text { of these } \\
\text { symptoms } \\
\text { (dizziness, } \\
\text { headache, } \\
\text { unsteady } \\
\text { gait and } \\
\text { vomiting)? }\end{array}$ & $\begin{array}{c}\text { Hypoglycaemic } \\
41 \%\end{array}$ & $\begin{array}{c}\text { Middle ear } \\
\text { disease } 66 \%\end{array}$ & $\begin{array}{c}\text { Hypertension } \\
25.5 \%\end{array}$ & $\begin{array}{c}\text { Head trauma } \\
\text { (Concussion) } \\
62 \%\end{array}$ & $\begin{array}{c}\text { I don't know } \\
5.6 \%\end{array}$ & & \\
\hline
\end{tabular}




\begin{tabular}{|c|c|c|c|c|c|c|c|c|}
\hline $\begin{array}{l}\text { Is nystagmus } \\
\text { consider sign } \\
\text { associated } \\
\text { with of having } \\
\text { vertigo? }\end{array}$ & usually 65\% & Always $11.2 \%$ & Never $6.2 \%$ & $\begin{array}{c}\text { I don't know } \\
17.5 \%\end{array}$ & & & & \\
\hline $\begin{array}{l}\text { Can unsteady } \\
\text { gait or } \\
\text { sudden fall } \\
\text { be associated } \\
\text { with vertigo? }\end{array}$ & usually 69\% & Always 7.9\% & Never $11.8 \%$ & $\begin{array}{c}\text { I don't Know } \\
11.8 \%\end{array}$ & & & & \\
\hline $\begin{array}{l}\text { Is vertigo } \\
\text { considered to } \\
\text { be a part of } \\
\text { dizziness? }\end{array}$ & yes $62.7 \%$ & No $32.4 \%$ & $\begin{array}{c}\text { I don't know } \\
6.8 \%\end{array}$ & & & & & \\
\hline $\begin{array}{c}\text { Can vertigo } \\
\text { be associated } \\
\text { with } \\
\text { migraine? }\end{array}$ & Yes 90\% & No $19.3 \%$ & $\begin{array}{c}\text { I don't know } \\
20 \%\end{array}$ & & & & & \\
\hline $\begin{array}{l}\text { A dizzy } \\
\text { patient in the } \\
\text { emergency } \\
\text { room must be } \\
\text { evaluated by? }\end{array}$ & ENT $47.2 \%$ & $\begin{array}{l}\text { Orthopedic } \\
2.6 \%\end{array}$ & $\begin{array}{l}\text { Internal } \\
\text { medicine } \\
14.9 \%\end{array}$ & $\begin{array}{c}\text { Emergency } \\
\text { physician } \\
62.7 \%\end{array}$ & $\begin{array}{c}\text { Neurology / } \\
\text { neurosurgeon } \\
40.4 \%\end{array}$ & $\begin{array}{c}\text { Audiologist } \\
\text { \vestibular } \\
\text { therapist } \\
34.2 \%\end{array}$ & & \\
\hline $\begin{array}{l}\text { Do you know } \\
\text { any these } \\
\text { clinical tests? }\end{array}$ & $\begin{array}{c}\text { Rhomberg test } \\
72.7 \%\end{array}$ & $\begin{array}{c}\text { Fukuda } \\
\text { stepping test } \\
24.2 \%\end{array}$ & $\begin{array}{c}\text { Dix-Hallpike } \\
62.7 \%\end{array}$ & $\begin{array}{l}\text { Gait walking } \\
\text { test } 46.6 \%\end{array}$ & $\begin{array}{l}\text { Head shaking } \\
\text { test } 53.4 \%\end{array}$ & $\begin{array}{l}\text { Ocolar motor } \\
\text { vestibular } \\
\text { test (Saccade, } \\
\text { tracking, } \\
\text { optoknetic) } \\
49 \%\end{array}$ & $\begin{array}{l}\text { Neurological } \\
\text { test (Skew } \\
\text { deviation, test, } \\
\text { VAT) 38\% }\end{array}$ & $\begin{array}{l}\text { None } \\
7.5 \%\end{array}$ \\
\hline $\begin{array}{l}\text { Have you done } \\
\text { any of the } \\
\text { previous tests } \\
\text { before? }\end{array}$ & Yes 74.5\% & No $25.3 \%$ & & & & & & \\
\hline $\begin{array}{l}\text { Does any of } \\
\text { the clinical } \\
\text { tests make it } \\
\text { easier for you } \\
\text { to diagnose } \\
\text { patients }\end{array}$ & Yes $86.3 \%$ & No $13.7 \%$ & & & & & & \\
\hline $\begin{array}{l}\text { Is vestibular } \\
\text { neuritis more } \\
\text { likely be } \\
\text { to develop } \\
\text { after Upper } \\
\text { respiratory } \\
\text { infection? }\end{array}$ & Yes $43.5 \%$ & No $7.5 \%$ & $\begin{array}{c}\text { I don't know } \\
49.1 \%\end{array}$ & & & & & \\
\hline $\begin{array}{c}\text { Negative } \\
\text { Dix- Hallpike } \\
\text { manoeuvre } \\
\text { will rule out } \\
\text { vertigo and } \\
\text { dizziness } \\
\text { patients? }\end{array}$ & Yes $19.5 \%$ & No $47.5 \%$ & $\begin{array}{c}\text { I don't know } \\
32.9 \%\end{array}$ & & & & & \\
\hline $\begin{array}{c}\text { Can basilar } \\
\text { artery } \\
\text { dissection } \\
\text { develop } \\
\text { vestibular } \\
\text { impairment? }\end{array}$ & Yes $54.5 \%$ & No $6 \%$ & $\begin{array}{c}\text { I don't know } \\
39.6 \%\end{array}$ & & & & & \\
\hline $\begin{array}{l}\text { What is the } \\
\text { most common } \\
\text { vestibular } \\
\text { disorder }\end{array}$ & $\begin{array}{c}\text { Benign } \\
\text { paroxysmal } \\
\text { positional } 67.1 \%\end{array}$ & $\begin{array}{c}\text { Meniere’s } \\
\text { disease } 6.2 \%\end{array}$ & $\begin{array}{c}\text { Ototoxicity } \\
3.1 \%\end{array}$ & $\begin{array}{l}\text { perilymph } \\
\text { fistula } 0 \%\end{array}$ & $\begin{array}{c}\text { I don't know } \\
24 \%\end{array}$ & & & \\
\hline
\end{tabular}




\begin{tabular}{|c|c|c|c|c|c|c|c|}
\hline $\begin{array}{l}\text { Which of the } \\
\text { following tests } \\
\text { can help you } \\
\text { in diagnosing } \\
\text { benign } \\
\text { paroxysmal } \\
\text { position } \\
\text { vertigo? }\end{array}$ & $\begin{array}{c}\text { Video head } \\
\text { Impulse } \backslash \text { Thrust } \\
\text { test } 6.8 \%\end{array}$ & $\begin{array}{c}\text { Vestibular } \\
\text { evoked } \\
\text { myogenic } \\
\text { protentional } \\
7.5 \%\end{array}$ & $\begin{array}{c}\text { The Dix- } \\
\text { Hallpike/ } \\
\text { supine roll } \\
\text { test using VNG } \\
68.3 \%\end{array}$ & $\begin{array}{c}\text { I don't } \\
\text { know29.2\% }\end{array}$ & & & \\
\hline $\begin{array}{c}\text { How can } \\
\text { differentiate } \\
\text { between } \\
\text { central and } \\
\text { peripheral } \\
\text { causes of } \\
\text { vertigo? }\end{array}$ & $\begin{array}{c}\text { Direction of the } \\
\text { nystagmus } 56.5 \%\end{array}$ & $\begin{array}{l}\text { Vestibular } \\
\text { tests } 40.4 \%\end{array}$ & $\begin{array}{c}\text { Associated } \\
\text { symptoms } \\
42.9 \%\end{array}$ & $\begin{array}{c}\text { Absence } \\
\text { of CNS } \\
\text { symptoms } \\
34.8 \%\end{array}$ & $\begin{array}{l}\text { I don't know } \\
24.5 \%\end{array}$ & & \\
\hline $\begin{array}{l}\text { When do you } \\
\text { refer patients } \\
\text { with dizziness } \\
\text { or vertigo to } \\
\text { the neurology } \\
\text { department? }\end{array}$ & $\begin{array}{c}\text { persisted } \\
\text { nystagmus more } \\
\text { than } 48 \text { hours not } \\
\text { positional } 50.6 \%\end{array}$ & $\begin{array}{c}\text { Acute vertigo } \\
22.4 \%\end{array}$ & $\begin{array}{c}\text { Sever } \\
\text { headache } \\
52.2 \%\end{array}$ & $\begin{array}{c}\text { Sudden } \\
\text { Unilateral } \\
\text { deafness } \\
35.1 \%\end{array}$ & $\begin{array}{l}\text { facial nerve } \\
\text { palsy } 46 \%\end{array}$ & $\begin{array}{c}\text { I don't know } \\
16.1 \%\end{array}$ & \\
\hline $\begin{array}{l}\text { When do you } \\
\text { refer patients } \\
\text { with dizziness } \\
\text { or vertigo to } \\
\text { ENT? }\end{array}$ & $\begin{array}{l}\text { Hearing loss } \\
\quad 67.1 \%\end{array}$ & $\begin{array}{c}\text { Aural fullness } \\
44.7 \%\end{array}$ & $\begin{array}{c}\text { Acute / } \\
\text { chronic } \\
\text { vertigo } 404 \%\end{array}$ & $\begin{array}{c}\text { Recent ear/ } \\
\text { neck surgeries } \\
46 \%\end{array}$ & $\begin{array}{c}\text { chronic middle } \\
\text { ear diseases } \\
65.2 \%\end{array}$ & $\begin{array}{c}\text { loss of } \\
\text { conscious } \\
12.4 \%\end{array}$ & $\begin{array}{c}\text { I don't know } \\
14.9 \%\end{array}$ \\
\hline
\end{tabular}

\section{Discussion}

The purpose of the study was to evaluate the knowledge of the healthcare providers on the differences between vertigo and dizziness. The second part of this study is to compare a different referring criterion among Saudi Arabia hospitals which still under process as of the time being. In our study we have found that there were fluctuations in the knowledge among specialties [9-11]. However, the percentage of participating physicians where lower compared to all health professionals in the study. Wherein there were only 75 physician participants while they were 86 therapist participants. This is the first study evaluating the knowledge of healthcare providers on the differences between vertigo and dizziness. The questionnaire was divided in two sections wherein the first part evaluates the knowledge of the basics of vestibular system. The second part of the questionnaire evaluates the knowledge of the vestibular diagnoses and vestibular disorders $[12,13]$.

In our study, it appeared that there were differences in acknowledging vertigo especially at the first part of questionnaire. From the 144 participants, $93.8 \%$ or 134 respondents answered with spinning or rotation symptom, $3.1 \%$ of the respondents answered with fainting, $2.5 \%$ of the respondents answered with unsteady gait while $0.6 \%$ of the respondents answered I don't know. In our second question, we asked the same concept but in different manner, surprisingly $82 \%$ of the respondents answered correctly with vertigo, $10.6 \%$ answered imbalance, $4.3 \%$ answered lightheadedness, and $3.1 \%$ of the respondents said they don't know. Vertigo can be associated with nausea/vomiting, tinnitus, hearing loss, and aural fullness wherein $87.7 \%$ only of the respondents answered correctly (all the above) as it is might be all present with dizzy patients.

Upon evaluation of the recognition of the participants on the possible causes of presenting symptoms - dizziness, headache, unsteady gait and vomiting, most participants associated it with middle ear disease, followed by head trauma, hypoglycemia, hypertension lastly with participants saying that they don't know yielding with a $66 \%, 62 \%, 41 \%, 25.5 \%$, and $5.6 \%$ result respectively. The consideration of nystagmus as a sign associated with vertigo showed that participants usually associated it with the disorder with $65 \%$ result, followed by a $17.5 \%$ responded they have no idea, $11.2 \%$ considered it as always, a sign of the disorder while $6.2 \%$ responded that it is never a sign for vertigo. On the association of unsteady gait and sudden fall to vertigo, results showed that the participants usually associated it yielding a 69\% result, an $11.8 \%$ result however for both respondents that they never associate it with vertigo and respondents who don't know, while $7.5 \%$ of the respondents always considered it as a sign for vertigo. When we asked them of the association of vertigo to migraine, most of the participants responded with $61 \%$ 'yes' answer, while an almost same percentage for $19 \%$ picked No, and $20 \%$ they do not know if migraine can be the main cause of having vertigo [14].

Any dizzy patients in the emergency room must be evaluated by emergency physician first than the referring will depend on the present symptoms .Recording to the participants, dizzy patients in the emergency room must be evaluated by emergency physician (62.7\%), flowed by ENT(47\%),and by Neurology \neurosurgeon (40\%) those were Higley recognized by the respondent to do the evaluation while in the middle recognition stand the audiologist $\backslash$ 
vestibular therapist (34\%), and lastly the Internal medicine (14\%) and (2.6\%) Orthopedic (2.6\%) [15].

The second part of the questionnaire evaluates the extent of knowledge of the participants on vestibular tests and disorders. They were primarily asked what diagnostic tests they are familiar with. The participants are most familiar with Romberg test and DixHallpike test with $72.7 \%$ and $62.7 \%$ respectively. Their familiarity with Head Shaking test and Ocular Motor Vestibular test showed $53.4 \%$ and $49 \%$ results respectively. Followed by Gait Walking test, Neurological test and Fuchida Stepping test that yielded a 46.6\%, $38 \%$ and $24.2 \%$ results respectively. However, it also showed that $7.5 \%$ of the participants are not familiar with any of the tests. There were about $74.5 \%$ of the participants who already did the mentioned tests, while 25.5 haven't done any of these. Furthermore, a high percentage of $83.3 \%$ of the participants consider these clinical tests to diagnose the patients easier [16].

Vestibular neuritis is a disorder that affects the nerve of the inner ear called the vestibulocochlear nerve. The disorder may cause a person to experience such symptoms as dizziness, balance difficulties, nausea, vomiting, concentration difficulties and sudden severe vertigo. When participants are asked if this occurs after an upper respiratory infection, $49.1 \%$ of the respondents answered they don't know, $43.5 \%$ said yes while $7.5 \%$ of them said no. In 2018 Jonathan D. Talmud and Scott C. DeLeon study reported that " Dix-Hallpike maneuver is the gold standard for diagnosis of benign positional paroxysmal vertigo, so it is difficult to assess its sensitivity and specificity acutely" 11 . So, having any negative DixHallpike does not mean rule out any vertigo and dizziness patients.

Dix-Hallpike test is a diagnostic maneuver used to identify benign paroxysmal positional vertigo. Evaluating the view of the participants whether a negative result rules out vertigo and dizziness to patients, $47.5 \%$ answered with 'No', 32.9\% answered with 'I don't know' and 19.5\% answered with 'yes'. Basilar artery dissection is a rare disease with high morbidity and mortality. A slightly more than half of the participants or $54.5 \%$ considers that it can develop to vestibular impairment, while $39.6 \%$ of them answered they have no idea and only 6\% answered with no. The participants were asked if what is the most common vestibular disorder among the choices, $67.1 \%$ of them answered with benign paroxysmal positional vertigo, $6.2 \%$ answered with Meniere's disease, $3.1 \%$ with ototoxicity while $24 \%$ or quite several them answered they don't know. They were also asked to choose only one from the choices that can help diagnose benign paroxysmal positional vertigo. The Dix-Hallpike was chosen by $68.3 \%$ of the participants, followed by vestibular evoked myogenic potentials and video head impulse/thrust test with $7.5 \%$ and $6.8 \%$ respectively. However, $29.2 \%$ of them do not know any of the tests to help diagnosing BPPV.

They were asked among the choices which can differentiate between central and peripheral causes of vertigo. The direction of the nystagmus was highly chosen with $56.5 \%$ response, associated symptoms with $42.9 \%$, vestibular tests with $40.4 \%$, absence of CNS symptoms with $34.8 \%$ and a $29.2 \%$ response for 'I don't know'. The evaluation of participants in recognizing when to refer patients with dizziness or vertigo to the neurology department was also done. Most likely the participants will refer the patients to the neurology department if they have a severe headache with a $52.2 \%$ response then with non-positional nystagmus of more than 48 hours with $50.6 \%$ response. About $46 \%$ and $35.1 \%$ of the participants will likely refer patients to the mentioned department if they have facial nerve palsy and sudden unilateral deafness respectively. Having an acute vertigo was the least chosen among the mentioned signs and symptoms with $22.4 \%$ response while $16.1 \%$ of the respondents don't know $[17,18]$.

On the other hand, they are also evaluated on which signs and symptoms in the choices will they refer the patients with dizziness and vertigo to ENT. The participants will most likely refer them to an ENT if they experience hearing loss and they have a chronic middle ear disease with $67.1 \%$ and $65.2 \%$ responses respectively. A response of $46 \%$ of them had chosen recent ear/neck surgeries, $44.7 \%$ of the participants also had chosen aural fullness, $40.4 \%$ had also chosen acute/chronic vertigo. Least likely they will refer the patients to the ENT if they had loss of consciousness with $12.4 \%$ while $14.9 \%$ of them have no idea.

\section{Conclusion}

There are a quiet several participants in the study that were found to be lacking the basic knowledge of dizziness and vertigo 64.1\% Moreover, upon going deeper in the study by giving more thorough questions, a plurality of them were found to be challenged especially in the protocols of diagnosing. This study might help increase awareness for the concerned ministry to acknowledge the lack of it. The aim is to improve and expand the level of education and further hone the skills of the healthcare providers especially in the field of ENT, ER, Family Medicine, Internal Medicine and Neurology. The next step after which is to compare the sensitivity and specificity of different referral criteria among Saudi Arabia hospitals and establishing a new referring criterion for these patients.

\section{Acknowledgment}

We express our gratitude to each doctor who assisted us in developing and testing questionnaires.

\section{References}

1. Centers for disease control and prevention. vital and health statistics, national ambulatory medical care survey (1991). In: summary: National Center for Health Statistics, Public Health Service, US Dept of Health and Human Services; 1994. DHHS publication, Washington, USA, pp. 941777.

2. National institute on deafness and other communication disorders. national strategic research plan $(1991,1992,1993)$ In: Department of Health and Human Services; Public Health Service, US Dept of Health and Human Services; 1994. NIH Publication, Washington, USA, PP: 953711.

3. Agrawal Y, Carey JP, Della Santina CC, Schubert MC, Minor LB (2009) Disorders of balance and vestibular function in US adults. Arch Intern Med 169(10): 938-944. 
4. (2009) National Institute on deafness and other communication disorders (NIDCD). Strategic plan (FY 2006-2008)

5. Soumyajit Das, Suvamoy Chakraborty, Sridutt Shekar (2017) Dizziness in a tertiary care centre in sikkim: our experience and limitations. Indian J Otolaryngol Head Neck Surg 69(4): 443-448.

6. Dizziness \& Balance Medical History Questionnaire by vestibular disorders associations.

7. Kameswaran M, Pujari S, Basumatary L, Singh J, Sarda K et al. (2017) Knowledge, attitudes and practices relating to vertigo among newly diagnosed patients: findings of a prospective observational registry in India. J Assoc Physicians India 65(3): 26-33.

8. Kevin A Kerber (2009) Vertigo and dizziness in the emergency department. department of neurology, university of michigan health system. Emerg Med Clin North Am 27(1): 39

9. Zhao J, Piccirillo J, Spitznagel E, Kallogjeri D, Goebel J, et al. (2011) Predictive Capability of Historical Data for Diagnosis of Dizziness. Otol Neurotol 32(2): 284-290.

10. Baloh RW (1997) Neurotology of migraine. Headache 37(10): 615-621.

11. Jonathan D Talmud, Scott C Dulebohn (2018) Dix hallpike maneuver.
12. Dix M, Hallpike CS (1952) The pathology, symptomatology and diagnosis of certain common disorders of the vestibular system. Ann Otol Rhinol Laryngol 61(4): 987-1016.

13. Clemis J, BeckerM (2011) Vestibular neuronitis. Otolaryngol Clin NAm 42(4): 361-365.

14. Kerber KA (2009) Vertigo and dizziness in the emergency department. Emerg Med Clin North Am 27(1): 39-50.

15. Zur 0, Carmeli E (2014) The university of California los angeles dizziness questionnaire: advantages and disadvantages. Journal of Vestibular Research 23(6): 279-283.

16. Grill E, Strupp M, Muller M, Jahn K (2014) Health services utilization of patients with vertigo in primary care: A Retrospective Cohort Study. J Neurol 261(8): 1492-1498.

17. Cappello M, Blasi U, Piazza L, Ducato G, Ferrara A, et al. (1995) Dizziness and vertigo in a department of emergency medicine. Eur J Emerg Med 2: 201-211.

18. Drachman DA, Hart CW (1972) An approach to the dizzy patient. Neurology 22(4): 323-334.
Creative Commons Attribution 4.0 International License

For possible submissions Click Here

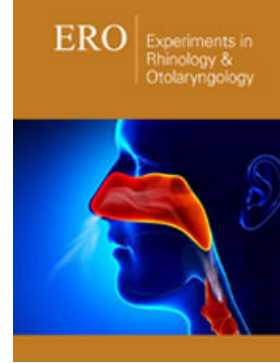

Experiments in Rhinology \& Otolaryngology

\section{Benefits of Publishing with us}

- High-level peer review and editorial services

- Freely accessible online immediately upon publication

- Authors retain the copyright to their work

- Licensing it under a Creative Commons license

- Visibility through different online platforms 